\title{
СТАН УМОВ ПРАЦІ ПРАЦІВНИКІВ ПРОМИСЛОВИХ ПІДПРИЕМСТВ ТА ЯКІСТЬ АТМОСФЕРНОГО ПОВІТРЯ ЕКОЛОГІЧНО НЕБЕЗПЕЧНОГО РЕГІОНУ
}

\section{Павленко О. І., Орєхова О. В.}

\section{ВСТУП}

Серед багатьох чинників, що впливають на довкілля та здоров'я населення, одне з головних місць посідають атмосферні забруднення ${ }^{1}$, які у структурі економічних втрат валового внутрішнього продукту від смертності і захворюваності населення займають друге місце ${ }^{2}$.

Проблема моніторингу стану атмосферного повітря та прогнозування його забруднення на цей час набуває першочергового значення, особливо у великих промислових регіонах ${ }^{3}$. За даними ВОО3, щорічно 7 мільйонів смертей пов'язано з впливом забруднення повітря, кожна 8-ма смерть у світі викликана серцевосудинними захворюваннями у результаті забруднення повітря, через забруднення збільшується ризик захворіти астмою на 15\%. Майже 98\% об’єму викидів припадає на чотири забруднювача - зважені частки, діоксид вуглецю, оксиди азоту, оксиди вуглецю ${ }^{4}$, а підвищення концентрації $\mathrm{PM}_{10}$ на $0,01 \mathrm{M \Gamma} / \mathrm{M}^{3}$ викликає зростання загальної смертності на $1 \%$, смертності від серцево-судинних захворювань - на $1,4 \%$, від хвороб органів дихання - на $3,4 \%$. Вплив лише зважених часток зменшує очікувану тривалість життя

${ }^{1}$ Турос О.І., Маремуха Т.П., Петросян А.А., Брезицька Н.В. Дослідження забруднення атмосферного повітря зваженими частинками пилу (РМ та РМ10) у м. Києві. Довкілля та здоров'я. 2018. № 4. С. 36-39. https://doi.org/ 10.32402/ dovkil2018.04.036.

2 Черниченко I.О., Баленко Н.В., Цимбалюк С.М., Осташ О.М. Про можливі механізми впливу атмосферних забруднень формальдегідом на формування захворюваності населення на рак щитоподібної залози. Довкілля та здоров'я. 2016. № 2. С. 9-13.

3 Добровольская Л.А., Клюев Д.С. Прогнозирование степени загрязнения атмосферного воздуха в промышленном регионе. Вісник приазовського державного технічного університету. 2018. Вип. 36. С. 216-223. doi: 10.31498/2225-6733.36. 2018.142552

${ }^{4}$ Гребняк М.П., Федорченко Р.А. Принципи профілактики шкідливого впливу індустріальних атмосферних забруднень на стан здоров'я населення. Довкілля та здоров'я. 2018. № 1. С. 51-56. https://doi.org/10.32402/dovkil2018.01.051 
в середньому на 1 рік ${ }^{5}$. Можливі соціально-економічні збитки від викидів зважених часток пилу з аеродинамічним діаметром часток до 10 мкм (виражені у вартісних показниках) для гірничорудного підприємства становлять 0,3-2,5 млн грн ${ }^{6}$.

Постійне мешкання у промисловому місті несприятливо впливає на стан здоров'я. Так, у 53,8 $22,5 \%$ мешканців промислового міста наявні відхилення вентиляційної функції внаслідок розвитку обструктивних змін бронхолегеневого апарату верхніх дихальних шляхів. 3 віком зростає питома вага осіб з дозонологічними станами функції зовнішнього дихання, особливо у віці 3039 та $40-49$ років $^{7}$.

За даними Держкомстату ${ }^{8}$, станом на 31 грудня 2017 року кількість працівників, які працюють в умовах, що не відповідають санітарно-гігієнічним нормам, становила майже 838,6 тис. осіб. 3 них у металургійному виробництві та виробництві готових металевих виробів - 105,1 тис. осіб (56,3\% до облікової кількості штатних працівників). 3 них працюють під впливом перевищення ГДР, ГДК (у\% до облікової кількості штатних працівників) за шкідливими хімічними речовинами $1-2$ та 3-4 класу небезпеки $31,9 \%$, за пилом переважно фіброгенної дії - 26,7\%, вібрації - 5,5\%, за шумом, інфра-, ультразвуком - 37,6\%, за несприятливим мікрокліматом у приміщенні - 33,6\%, за важкістю праці - 23,4\%, за напруженістю праці - 27,0\%, за дії інших факторів - 4,3\%. У добувній промисловості та розробленні кар'єрів - 144,5 тис. осіб (67,9\% до облікової кількості штатних працівників), 3 них працюють під впливом перевищення ГДР, ГДК (у\% до облікової кількості штатних працівників) за шкідливими хімічними речовинами 1-2 та 3-4 класу небезпеки - 26,9\%, за пилом переважно фіброгенної дії - 22,4\%, вібрації - 12,2\%, за шумом, інфра-, ультразвуком - 42,8\%, за несприятливим мікрокліматом

${ }^{5}$ Карелин А.О., Ломтев А.Ю., Мозжухина Н.А., Еремин Г.Б., Никонов В.А. Методические проблемы мониторинга мелкодисперсных частиц в атмосферном воздухе населенных мест. Гигиена и санитария. 2016. 95(10). С. 985-988. doi.org/10.1882/0016-9900-2016-10-985-988.

${ }_{6}$ Давиденко Г.М. Гігієнічна оцінка небезпеки здоров'ю населення від забруднення атмосферного повітря зваженими частками пилу : автореф. дис. ... канд. біол. наук : 14.02.01. Київ, 2017. 24 с.

7 Гребняк М.П., Федорченко Р.А. Гігієнічна донозологічна діагностика впливу атмосферних забруднень на органи дихання. Довкілля та здоров я. 2017. № 1. С. 15-18.

8 База даних Держкомстату. URL: http://www.ukrstat.gov.ua (дата звернення: 01.10.2020). 
у приміщенні - 37,0\%, за несприятливої температури зовнішнього повітря або атмосферного тиску - 0,3\%, за важкістю праці - 35,2\%, за напруженістю праці - 40,3\%, за дії інших факторів -6,1\%.

Кількість працівників, які працюють в умовах, що не відповідають санітарно-гігієнічним нормам за регіонами, наступна: перше місце посідає Донецька область - 159,8 тис. осіб, друге місце - Дніпропетровська область - 104 тис. осіб, третє місце - Запорізька область 64,5 тис. осіб, четверте місце - Харківська область - 57,4 тис. осіб. Питома вага працівників, які працюють під впливом шкідливих факторів за регіонами, станом на 31 грудня 2017 року (у\% до облікової кількості штатних працівників) наступна: Донецька область - 47,1\%, Дніпропетровська область - 42,1\%, Запорізька область - 36,8\% при середньому показнику по Україні - 28,4\%.

Зазначена ситуація вимагає необхідності розробки і впровадження у екологічно небезпечних містах спеціальних програм щодо покращення стану умов праці та якості атмосферного повітря. Також $\epsilon$ необхідність обгрунтування принципів кількісного оцінювання інтенсивності впливу факторів навколишнього природного середовища на захворюваність населення 3 оцінкою соціальних втрат / збитків здоров'ю населенню, яке проживає в екологічно небезпечному регіоні.

Таким чином, метою досліджень було проведення поглибленого гігієнічного дослідження стану умов праці працівників промислових підприємств та якості атмосферного повітря екологічно небезпечного регіону.

\section{1. Гігієнічна характеристика умов праці працівників сучасної гірничо-металургійної галузі}

Результати проведених комплексних гігієнічних досліджень умов праці працівників основних професій сучасного гірничозбагачувального та металургійного виробництва свідчать про те, що основна кількість працівників працює у шкідливих, важких та напружених умовах.

Вкотре доведено, що провідними шкідливими факторами виробничого середовища для основних професій сучасного гірничозбагачувального та металургійного виробництва $є$ : несприятливий мікроклімат, шум, вібрація, пил, переважно фіброгенної дії, шкідливі хімічні речовини, важка та напружена праця, а умови 
праці й на сьогоднішній день продовжують залишатись шкідливими важкими та напруженими.

Так, провідними несприятливими шкідливими виробничими факторами є пил переважно фіброгенної дії та шкідливі хімічні речовини, наявність яких на робочих місцях 60\% працівників сучасного гірничо-збагачувального підприємства відносять умови праці за цим показником до 3 класу 3 ступеня шкідливості (робочі місця агломератника, дозувальника гарячого повертання, дозувальника низу шихтового відділення, дробильника, машиніста конвеєру, бункерувальника), по $20 \%$ робочих місць за наявністю пилу та шкідливих хімічних речовин можна віднести до 3 класу 2 ступеня шкідливості (машиніст екскаватора, машиніст бурової установки) та до 3 класу 1 ступеня шкідливості (машиніст електровозу, водій автотранспортних засобів).

Наявний несприятливий мікроклімат 3 класу 2 ступеню має місце на $60 \%$ робочих місць, які аналізувались (агломератник, дозувальник гарячого повертання, машиніст екскаватора, машиніст бурової установки, машиніст електровозу, водій автотранспортних засобів). Лише 40\% робочих місць (дозувальник низу шихтового відділення, дробильник, машиніст конвеєра, бункерувальник) характеризується параметрами мікроклімату 3 класу 1 ступеню шкідливості.

Еквівалентний рівень шуму на робочому місці дробильника досягає 99 дБА, що належить до 3 класу 3 ступеню шкідливості. Умови праці на робочому місці агломератника, дозувальника низу шихтового відділення, дозувальника гарячого повертання, машиніста бурової установки, машиніста конвеєра, бункерувальника $(60 \%)$ за рівнем еквівалентного шуму відносяться до 3 класу 2 ступеню шкідливості. Робоче місце машиніста екскаватора за рівнем еквівалентного шуму відноситься до 3 класу 1 ступеню шкідливості. Робочі місця машиніста електровозу та водія автотранспортних засобів - до 2 класу допустимого.

Особливістю умов праці сучасного гірничо-збагачувального виробництва $\epsilon$ технологічні операції, машини та механізми, які генерують вібрацію. Так, на робочому місці водія автотранспортних засобів генерується такий рівень еквівалентної вібрації, який згідно з гігієнічною класифікацією праці відносить робоче місце водія до 3 класу 2 ступеню шкідливого, а робоче місце агломератника, дробильника, машиніста екскаватора, машиніста бурової установки - до 3 класу 1 ступеню шкідливості. 
Всі робочі місця (100\%) гірничо-збагачувального підприємства, які аналізувались, характеризуються важкими умовами праці за рахунок незручної / фіксованої / вимушеної робочої пози, нахилів тулубу та маси вантажу (дробильник), які згідно з гігієнічною класифікацією праці відносяться до 3 класу 2 ступеня шкідливості.

Умови праці за показниками напруженості праці у працівників сучасного гірничо-збагачувального виробництва (дробильник, машиніст екскаватора, машиніст бурової установки, водій автотранспортних засобів, машиніст конвеєра, бункерувальник) за рахунок ступеню відповідальності за безпеку інших осіб, а саме працівники є відповідальними за безпеку, що відноситься до 3 класу 2 ступеню шкідливості. Робоче місце агломератника, дозувальника гарячого повертання, дозувальника низу шихтового відділення, машиніста електровозу за показниками напруженості характеризується наявністю ризику для власного життя та життя інших осіб та 12-ти годинним робочим днем з роботою у нічну зміну, що згідно з гігієнічною класифікацією праці відноситься до 3 класу 1 ступеню шкідливості.

У працівників основних професій сучасного металургійного виробництва має місце високий рівень пилу переважно фіброгенної дії, який майже для всіх основних професій згідно з гігієнічною класифікацією праці відносяться до 3 класу 4 ступеню шкідливості і лише для операторських професій (оператор пульта керування стана гарячого прокату) до 2 класу допустимого. Найбільші рівні пилу переважно фіброгенної дії мають місце на робочих місцях працівників агломераційного та доменного цехів.

Нагріваючий мікроклімат, який згідно з гігієнічною класифікацією праці характеризується як 3 клас 4 ступінь шкідливості, має місце на робочому місці агломератника, горнового доменної печі, газівника доменної печі, міксерового та підручного міксерового конвертерного цеху, сталевара конвертера та підручного сталевара конвертера, ковшового, нагрівальника металу та різальника гарячого металу. Не менш важливим шкідливим виробничим фактором $є$ важка фізична праця, яка майже у всіх працівників основних професій згідно 3 гігієнічною класифікацією праці відноситься до 3 класу 2 ступеню шкідливості. У машиніста завалювальної машини, міксерового та підручного міксерового конвертерного цеху, розливальника сталі конвертерного цеху, 
оператора пульта керування стана гарячого прокату (4 професії, $17 \%$ ) характеризується 3 класом 1 ступеню шкідливості і лише у машиніста дистрибутора (1 професія, 4\%) - 2 класом.

При загальній гігієнічній оцінці умови праці працівників основних професій сучасного металургійного виробництва, згідно 3 гігієнічною класифікацією праці, відносяться до 3 класу 4 ступеню шкідливості. Умови праці машиніста дистрибутора та оператора пульта керування стана гарячого прокату відносяться до 3 класу 1 ступеню шкідливості.

\section{2. Гігіснічна оцінка якості атмосферного повітря екологічно небезпечного регіону}

Основними джерелами забруднення у Дніпропетровській області $\epsilon$ викиди забруднюючих речовин від стаціонарних і пересувних джерел, які згідно з офіційними статистичними даними сягають $17 \%$ від загального обсягу викидів в країні та становлять у розрахунку на одну особу 260,5 кг, а 3 розрахунку на 1 км $^{2}$ території - 26,8 т.

У Кривому Розі ці показники є ще вищими. Так, викиди на одну особу по Кривому Рогу вищі в 13,6 разів за Дніпропетровську область, а з розрахунку на $1 \mathrm{kм}^{2}$ території - в 1,9 рази. У порівнянні 3 Чернівецькою областю ця різниця вражає - 1314,8 та 167,5 відповідно (таблиця 1).

При цьому слід відзначити, що викиди забруднюючих речовин в атмосферне повітря в Чернівецькій області здійснюються в основному за рахунок пересувних джерел (в тому числі автомобільного транспорту) та становлять 37,3 $\pm 1,8$ кг/особу, що складає 92,33\% від загальних викидів забруднюючих речовин у контрольній групі (таблиця 2).

Згідно 3 інформацією, наведеною на офіційному вебсайті виконавчого комітету Криворізької міської ради, у Кривому Розі високий рівень забруднення повітря зумовлений збільшенням обсягів викидів забруднюючих речовин у 2019 році на 15\% порівняно з аналогічним періодом минулого року.

Так, обсяги викидів забруднюючих речовин збільшено ПАТ «АрселорМіттал Кривий Ріг» на 27\%, ПРАТ «ІНГЗК» на 15\%, ТОВ «МЕТІНВЕСТ-КРМЗ» на 13\%, ПРАТ «СУХА БАЛКА» на 3\%, ПРАТ «ЦГЗК» на $1,6 \%$. 
Таблиця 1

Рівень викидів забруднюючих речовин в умовно «чистому» та «забрудненому» регіонах України

\begin{tabular}{|l|c|c|c|c|}
\hline $\begin{array}{c}\text { Рівень } \\
\text { викидів }\end{array}$ & $\begin{array}{c}\text { Дніпропетровська } \\
\text { область }\end{array}$ & $\begin{array}{c}\text { Чернігівська } \\
\text { область }\end{array}$ & $\begin{array}{c}\text { Чернівецька } \\
\text { область }\end{array}$ & $\begin{array}{c}\text { м. Кривий } \\
\text { Ріг }\end{array}$ \\
\hline $\begin{array}{l}\text { Викиди } \\
\text { (кг/особу) }\end{array}$ & $260,5 \pm 26,3$ & $39,5 \pm 2,7$ & $2,7 \pm 0,26$ & $3550,9 \pm 150,5$ \\
\hline $\begin{array}{l}\text { Викиди } \\
\text { (км } / \text { кг) }\end{array}$ & $26807,5 \pm 53,74$ & $1312,4 \pm 90,5$ & $306,9 \pm 25,8$ & $51400,0 \pm 270,6$ \\
\hline
\end{tabular}

Таблиця 2

Рівень викидів забруднюючих речовин в атмосферне повітря в Чернівецькій області (тис. тонн)

\begin{tabular}{|l|c|c|c|c|}
\hline \multicolumn{1}{|c|}{ Джерело забруднення } & Median & $\begin{array}{c}\text { Percentile } \\
\mathbf{2 5 \%}\end{array}$ & $\begin{array}{c}\text { Percentile } \\
\mathbf{7 5 \%}\end{array}$ & $\begin{array}{c}\text { Рівень } \\
\text { викидів, } \\
\text { (кг/особу) }\end{array}$ \\
\hline $\begin{array}{l}\text { Викиди забруднюючих } \\
\text { речовин, усього, тис. т }\end{array}$ & 37,0 & 34,1 & 39,1 & $40,4 \pm 2,6$ \\
\hline $\begin{array}{l}\text { у тому числі від: } \\
\text { стаиіонарних джерел }\end{array}$ & 2,7 & 2,5 & 3,2 & $3,1 \pm 0,26$ \\
\hline $\begin{array}{l}\text { пересувних джерел } \\
\text { (в тому числі автомо- } \\
\text { більний транспорт) }\end{array}$ & 34,5 & 30,9 & 36,4 & $37,3 \pm 1,8$ \\
\hline
\end{tabular}

В Кривому Розі переважають стаціонарні джерела забруднення атмосферного повітря. Основним 3 яких є ПАТ «АрселорМіттал Кривий Ріг», що дає до 70\% викидів в навколишнє середовище міста.

Спроможність атмосфери розсіювати шкідливі домішки зумовлена різними природними факторами, комбінація яких у Криворізькому регіоні значно гальмує процес самоочищення атмосфери. Отже, значні викиди і обмежена здатність атмосфери міста до самоочищення сприяють особливому забрудненню повітря в нашому місті.

Проведений аналіз вмісту шкідливих хімічних речовин у атмосферному повітрі м. Кривий Ріг показав, що протягом року мали місце перевищення гранично допустимих максимально разових концентрацій пилу в $3,8-4,8$ рази, оксиду вуглецю 2,4 рази, діоксиду азоту в 2,00-2,75 рази, фенолу в 1,40-1,80 рази, формальдегіду в $1,74-3,37$ рази. Але, як свідчать отримані дані, 
забруднення повітря м. Кривий Ріг протягом року $є$ нерівномірним. Концентрації хімічних речовин в атмосферному повітрі, а відповідно їх сумарне забруднення, в різні періоди року мають деякі відмінності. Значною мірою визначаючою умовою цих відмінностей $€$ метеорологічні умови в той чи інший період року.

Поглиблений аналіз особливостей забруднення атмосферного повітря за сезонами року в основній групі дозволив визначити рівень та динаміку забруднення протягом річного проміжку часу.

Перевищення максимально разової концентрації формальдегіду по м. Кривий Ріг є найвищим 3 травня по вересень та коливається від 2,46 до 3,37 ГДК. У період з січня по березень концентрація формальдегіду в атмосферному повітрі не перевищує ГДК. 3 жовтня по грудень концентрація коливається у межах 1,03-1,51 ГДК. Середньомісячна концентрація формальдегіду протягом року значно перевищує ГДК та становить від 3,67 до 7,67 ГДК з середнім значенням по м. Кривий Ріг становить $0,013 \pm 0,005 \mathrm{Mг} / \mathrm{m}^{3}$ та у контрольній групі $0,0024 \pm 0,004 \mathrm{Mг} / \mathrm{M}^{3}$.

Концентрація фенолу у атмосферному повітрі у період 3 жовтня по січень є максимальною та становить 1,10-1,40 ГДК, у квітні, липні, серпні, вересні - $\epsilon$ мінімальною та становить 0,8-1,0 ГДК. Середньомісячна концентрація фенолу 3 лютого по травень становить 0,33 ГДК, а з червня по січень - 0,67 ГДК, що, відповідно, знаходиться у межах допустимих нормативів з середнім значенням по м. Кривий Ріг становить $0,0015 \pm 0,0005 \mathrm{мг} / \mathrm{M}^{3}$ та у контрольній групі $0,0018 \pm 0,002 \mathrm{мг} / \mathrm{M}^{3}$.

Максимально разова концентрація діоксиду азоту є найменшою 3 січня до березня та становить 0,7-0,95 ГДК, а найвищою 3 квітня по грудень в межах 1,00-2,75 ГДК. Середньомісячна концентрація діоксиду азоту 3 жовтня по квітень становить 1,0 ГДК, а 3 травня по вересень - 1,25 ГДК з середнім значенням по м. Кривий Ріг становить $0,045 \pm 0,005$ мг $/ \mathrm{M}^{3}$ та у контрольній групі $0,02 \pm 0,04 \mathrm{Mr} / \mathrm{M}^{3}$.

Максимально разова концентрація оксиду вуглецю лише у березні складає 0,8 ГДК. Протягом року концентрація оксиду вуглецю у м. Кривий Ріг коливається від 1,0 до 2,0 ГДК. Середньомісячна концентрація оксиду вуглецю з вересня по травень становить 0,67 ГДК, а з червня по серпень - від 1,00 до 1,33 ГДК з середнім значенням по м. Кривий Ріг становить $2,5 \pm 0,05 \mathrm{мг} / \mathrm{m}^{3}$ та у контрольній групі $0,3 \pm 0,1 \mathrm{Mг} / \mathrm{M}^{3}$. 
Максимально разова концентрація пилу є найменшою у грудні та січні та становить 1,80-2,40 ГДК. 3 лютого по листопад максимально разова концентрація пилу коливається від 3,0 до 4,8 ГДК. Середньомісячна концентрація пилу у січні становила 1,33 ГДК. У серпні та вересні - 4,0 ГДК з середнім значенням по м. Кривий Ріг становить $0,5 \pm 0,1 \mathrm{M \Gamma} / \mathrm{M}^{3}$ та у контрольній групі $0,105 \pm 0,2 \mathrm{Mг} / \mathrm{M}^{3}$ (таблиця 3).

Серед речовин забруднювачів, концентрація яких перевищувала ГДК протягом всіх сезонів року, на першому місці $є$ пил, на другому - формальдегід.

Максимальні концентрації пилу відмічались весною, що пов'язано з додатковим потраплянням іiі від природних джерел, частими штилями і слабими вітрами у приземному шарі атмосферного повітря.

Концентрації діоксиду сірки були найбільшими зимою та осінню, а в літній час - знижувались. Таке зниження можна пояснити закінченням опалювального сезону та зниженням вологості повітря.

Таким чином, встановлені регіональні метеорологічні особивості територій, що досліджувались, які впливають на формування характеру і ступеня техногенного забруднення приземного шару атмосфери основної та контрольної групи. При цьому визначення структури забруднення атмосферного повітря м. Кривий Ріг показало, що у різні пори року найбільша питома вага серед речовин забруднювачів складає пил, формальдегід, фенол, азоту діоксид, вуглецю оксид.

Дещо інший характер мало забруднення атмосферного повітря контрольної групи. Сезонні забруднення атмосферного повітря контрольної зони пилом у декілька разів нижче, ніж в основній групі, і концентрація пилу за сезонами на мала достовірних відмінностей. Концентрація двоокису азоту також у рази нижче у контрольній групі у порівнянні з основною групою та не мала достовірної сезонної динаміки. Концентрації двоокису сірки та фенолу в атмосферному повітрі були незначними та не залежали від пори року, а інколи навіть не визначались (таблиця 3).

За період, який аналізувався в центральному регіоні (в тому числі на території м. Кривий Ріг), здатність атмосфери до самоочищення знижується за рахунок збільшення повторюваності штилів та зменшення швидкості вітру на даній території, а в Чернівецькій області статистично достовірно умови для самоочищення атмосфери поліпшуються. 
За даними гідрометслужби, в контрольному регіоні є виключно сприятливі умови для самоочищення атмосфери $(\mathrm{K}=1,8)$, а по Дніпропетровському регіону (регіон дослідження) коефіцієнт самоочищення атмосфери вдвічі менший $(0.8 \leq K \leq 1.2)$ і відноситься до категорії обмежено / відносно сприятливі.

Найбільш сприятливі умови для самоочищення атмосфери спостерігаються з кінця зими до середини літа (лютий-липень).

Максимальних значень $K$ досягає у квітні - червні. 3 липня i до січня метеорологічні умови в Україні обмежено сприятливі для розсіювання домішок. У серпні та жовтні відмічаються найгірші умови для виведення забруднюючих речовин з атмосфери.

Таким чином, значні викиди і обмежена здатність атмосферного повітря міста до самоочищення сприяють особливому забрудненню повітря у м. Кривий Ріг, що потребує визначення та аналізу індексу забруднення атмосфери.

Індекс забруднення атмосфери (I3А) $є$ інтегральним показником забруднення та показує спроможність атмосфери до самоочищення (табл. 4).

Таблиця 3

Середньомісячні концентрації хімічних речовин в атмосферному повітрі основної та контрольної групи

\begin{tabular}{|c|c|c|}
\hline $\begin{array}{c}\text { Хімічна } \\
\text { речовина }\end{array}$ & 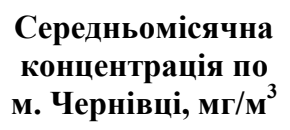 & $\begin{array}{c}\text { Середньомісячна } \\
\text { концентрація } \\
\text { м. Кривий Ріг, мг/м³ }\end{array}$ \\
\hline Пил & $0,105 \pm 0,2$ & $0,5 \pm 0,1$ \\
\hline Діоксид сірки & $0,004 \pm 0,0015$ & $0,021 \pm 0,01$ \\
\hline $\begin{array}{l}\text { Оксид } \\
\text { вуглецю }\end{array}$ & $0,3 \pm 0,1$ & $2,5 \pm 0,5$ \\
\hline Діоксид азоту & $0,02 \pm 0,04$ & $0,045 \pm 0,005$ \\
\hline Оксид азоту & $0,03 \pm 0,05$ & $0,02 \pm 0,01$ \\
\hline Фенол & $0,0018 \pm 0,002$ & $0,0015 \pm 0,0005$ \\
\hline $\begin{array}{l}\text { Фтористий } \\
\text { водень }\end{array}$ & $0,0035 \pm 0,0045$ & - \\
\hline $\begin{array}{l}\text { Хлористий } \\
\text { водень }\end{array}$ & $0,1 \pm 0,25$ & - \\
\hline Формальдегід & $0,0024 \pm 0,004$ & $0,013 \pm 0,005$ \\
\hline аміак & - & $0,01 \pm 0,005$ \\
\hline
\end{tabular}


Таблиця 4

Індекс забруднення атмосфери (I3A)

за середньомісячною концентрацією

\begin{tabular}{|c|c|c|c|c|}
\hline \multirow[b]{2}{*}{$\begin{array}{l}\text { Хімічна } \\
\text { речовина }\end{array}$} & \multicolumn{2}{|c|}{ м. Чернівці } & \multicolumn{2}{|c|}{ м. Кривий Ріг } \\
\hline & $\begin{array}{c}\text { концентрація } \\
\left(\mathrm{M \Gamma} / \mathrm{M}^{3}\right)\end{array}$ & I3A & $\begin{array}{c}\text { концентрація } \\
\left(\mathrm{M \Gamma} / \mathrm{M}^{3}\right)\end{array}$ & I3A \\
\hline Пил & 0,7 & 0,7 & 3,33 & 3,33 \\
\hline Діоксид сірки & 0,08 & 0,08 & 0,41 & 0,41 \\
\hline $\begin{array}{l}\text { Оксид } \\
\text { вуглецю }\end{array}$ & 0,1 & 0,125 & 0,84 & 0,85 \\
\hline Діоксид азоту & 0,5 & 0,406 & 1,13 & 1,17 \\
\hline Окис азоту & 0,05 & 0,05 & 0,33 & 0,33 \\
\hline Фенол & 0,6 & 0,514 & 0,5 & 0,41 \\
\hline Формальдегід & 0,8 & 0,748 & 4,33 & 6,72 \\
\hline аміак & - & - & 0,25 & 0,29 \\
\hline KI3A & & 3,657 & & 13,51 \\
\hline
\end{tabular}

Так, ІЗА за хімічними речовинами, які аналізувались по м. Кривий Ріг, коливається від 0,29 до 3,33, що відноситься до низького рівня забруднення атмосфери, але у порівнянні 3 контрольною групою $(0,05-0,7)$ вище у $4,75-5,8$ разів. Для формальдегіду показник ІЗА становить 6,72 для м. Кривий Ріг, що характеризується як підвищений та у 5,03 разів перевищує аналогічний показник контрольної групи.

Показник (комплексного індексу забруднення атмосфери) КІЗА характеризує рівень забруднення атмосфери 3 урахуванням комплексного впливу декількох хімічних речовин та становить по м. Кривий Ріг 13,51, а у контрольній групі - 3,657, що відповідно у 3,69 разів вище.

Забруднення атмосфери м. Кривий Ріг є більш вираженим, що потребує постійного санітарно-гігієнічного моніторингу якості атмосферного повітря сучасним лабораторним обладнанням 3 визначенням, в тому числі, концентрації пилу $\mathrm{PM}_{1}$.

Доведено, що по м. Чернівці перевищення максимально разової концентрації мало місце по фенолу (1,3 ГДК), фтористому водню (1,5 ГДК), хлористому водню (4,1 ГДК), формальдегіду (1,2 ГДК). Джерелом хлористого водню, фтористого водню, формальдегіду в Чернівецькій області є підприємства, які займаються виробництвом синтетичних барвників та смол на ВАТ «Чернівецький хімічний завод». 
Індекс забруднення атмосфери (IЗА)

за максимальноразовою концентрацією

\begin{tabular}{|c|c|c|c|c|}
\hline \multirow[b]{2}{*}{$\begin{array}{c}\text { Хімічна } \\
\text { речовина }\end{array}$} & \multicolumn{2}{|c|}{ м. Чернівці } & \multicolumn{2}{|c|}{ м. Кривий Ріг } \\
\hline & $\begin{array}{c}\text { Концентрація } \\
\left(\mathrm{Mr} / \mathrm{m}^{3}\right)\end{array}$ & I3A & $\begin{array}{c}\text { Концентрація } \\
\left(\mathrm{Mr} / \mathrm{M}^{3}\right)\end{array}$ & I3A \\
\hline Пил & $0,2 \pm 0,03$ & 0,2 & $4,8 \pm 0,8$ & 4,9 \\
\hline Діоксид сірки & $0,11 \pm 0,05$ & 0,11 & $0,13 \pm 0,025$ & 0,13 \\
\hline Окис вуглецю & $0,8 \pm 0,04$ & 0,82 & $2,4 \pm 0,7$ & 2,2 \\
\hline Діоксид азоту & $1,0 \pm 0,02$ & 1,0 & $2,75 \pm 0,8$ & 3,72 \\
\hline Окис азоту & $0,2 \pm 0,06$ & 0,2 & $0,25 \pm 0,05$ & 0,25 \\
\hline сірководень & - & - & $0,75 \pm 0,18$ & 0,68 \\
\hline Фенол & $1,3 \pm 0,2$ & 1,406 & $1,8 \pm 0,6$ & 2,15 \\
\hline Фтористий водень & $1,5 \pm 0,3$ & 1,69 & - & - \\
\hline Хлористий водень & $4,1 \pm 0,5$ & 6,26 & - & - \\
\hline Формальдегід & $1,2 \pm 0,15$ & 1,267 & $3,37 \pm 0,44$ & 4,85 \\
\hline аміак & - & - & $0,3 \pm 0,07$ & 0,33 \\
\hline KI3A & 9,0 & 12,95 & 16,55 & 19,21 \\
\hline
\end{tabular}

Таблиця 6

Середньодобова доза інгаляційного навантаження на легені хімічними речовинами 3 атмосферного повітря

\begin{tabular}{|c|c|c|c|c|c|c|}
\hline \multirow{3}{*}{$\begin{array}{c}\text { Хімічна } \\
\text { речовина }\end{array}$} & \multicolumn{4}{|c|}{$\begin{array}{c}\text { Середня добова доза речовини } \\
\text { ADD/LADD (мг/кг×доба) }\end{array}$} & \multirow{2}{*}{\multicolumn{2}{|c|}{$\begin{array}{c}\text { Перевищення } \\
\text { дози (рази) } \\
\text { м. Кривий ріг }\end{array}$}} \\
\hline & \multicolumn{2}{|c|}{ м. Чернівці } & \multicolumn{2}{|c|}{ м. Кривий ріг } & & \\
\hline & дорослі & діти & дорослі & діти & дорослі & діти \\
\hline Пил & 0,03 & 0,1428 & 0,1457 & 0,6802 & 4,8 & 4,76 \\
\hline Діоксид сірки & 0,0011 & 0,0054 & 0,0061 & 0,0285 & 5,55 & 5,27 \\
\hline Оксид вуглецю & 0,0874 & 0,40809 & 0,7284 & 3,401 & 8,33 & 8,34 \\
\hline Діоксид азоту & 0,00583 & 0,0272 & 0,0131 & 0,0612 & 2,24 & 2,25 \\
\hline Оксид азоту & 0,0087 & 0,0408 & 0,0058 & 0,0272 & 0,667 & 0,667 \\
\hline Фенол & 0,00052 & 0,00244 & 0,00043 & 0,0020 & 0,8269 & 0,8196 \\
\hline $\begin{array}{l}\text { Фтористий } \\
\text { водень }\end{array}$ & 0,00102 & 0,00476 & - & - & & \\
\hline $\begin{array}{l}\text { Хлористий } \\
\text { водень }\end{array}$ & 0,0291 & 0,13603 & - & - & & \\
\hline Формальдегід & 0,00069 & 0,00326 & 0,0037 & 0,0176 & 5,3623 & 5,398 \\
\hline аміак & - & - & 0,0029 & 0,0136 & & \\
\hline $\begin{array}{l}\text { Середнє } \\
\text { квадратичне } \\
\text { значення }\end{array}$ & 0,0974 & 0,4551 & 0,754 & 3,46 & 7,7412 & 7,602 \\
\hline
\end{tabular}


Таблиця 7

Неканцерогенний ризик впливу шкідливих хімічних речовин атмосферного повітря на населення (за середньомісячною концентрацісю)

\begin{tabular}{|c|c|c|c|c|}
\hline \multirow{2}{*}{$\begin{array}{c}\text { Хімічна } \\
\text { речовина } \\
\text { (середньомісячна } \\
\text { концентрація) }\end{array}$} & \multirow{2}{*}{$\begin{array}{l}\text { RfC, } \\
\mathbf{M} / \mathbf{M}^{3}\end{array}$} & \multicolumn{2}{|c|}{$\begin{array}{c}\text { Коефіцієнт небезпеки } \\
\text { HQ }\end{array}$} & \multirow{2}{*}{$\begin{array}{c}\text { Критичні органи } \\
\text { та системи }\end{array}$} \\
\hline & & м. Чернівці & $\begin{array}{c}\text { м. } \\
\text { Кривий } \\
\text { Ріг }\end{array}$ & \\
\hline Пил & 0,1 & 1,05 & 5,0 & Органи дихання \\
\hline Діоксид сірки & 0,05 & 0,08 & 0,42 & Органи дихання \\
\hline Оксид вуглецю & 3 & 0,1 & 0,83 & ЦНС, ССС, кров \\
\hline Діоксид азоту & 0,04 & 0,5 & 1,12 & Органи дихання \\
\hline Оксид азоту & 0,08 & 0,375 & 0,25 & Органи дихання \\
\hline Фенол & 0,006 & 0,3 & 0,25 & $\begin{array}{c}\text { ССС, нирки, ЦНС, } \\
\text { печінка }\end{array}$ \\
\hline $\begin{array}{l}\text { Фтористий } \\
\text { водень }\end{array}$ & 0,03 & 0,11 & - & $\begin{array}{l}\text { Органи дихання, } \\
\text { кісткова система }\end{array}$ \\
\hline $\begin{array}{l}\text { Хлористий } \\
\text { водень }\end{array}$ & 0,2 & 0,5 & - & Органи дихання \\
\hline Формальдегід & 0,003 & 0,8 & 4,33 & $\begin{array}{l}\text { Органи дихання, } \\
\text { імунна система }\end{array}$ \\
\hline Загальне НI & & 3,8 & 12,2 & \\
\hline $\begin{array}{l}\text { НІ для органів } \\
\text { дихання }\end{array}$ & & 3,4 & 11,12 & \\
\hline
\end{tabular}

* Дані по RfC наведено з урахуванням інформації WHO (Всесвітня організачія охорони здоров'я), СаlЕРA (Каліфорнійське Агентство з охорони навколишнього середовища), IRIS (інтегрована інформачійна система про ризики (U.S.EPA).

Оксиди азоту та вуглецю, а також бензопірен $є$ продуктами неповного згоряння палива автотранспорту Середньомісячна концентрація зазначених шкідливих хімічних речовин у м. Чернівці $\epsilon$ у межах гігієнічних нормативів для атмосферного повітря.

Для м. Кривий Ріг основними забруднювачами $є$ пил, діоксид азоту, формальдегід, а за максимальноразовою концентрацією до забруднювачів додається ще й фенол. 
При загальній гігієнічній оцінці рівень забруднення в Кривому Розі в 3,7 разів вищий за середньомісячною концентрацією i в 1,5 рази за максимальноразовою концентрацією i характеризується як «високий» і «дуже високий» рівень (табл. 5).

Дослідженнями встановлено, що середньодобова доза інгаляційного навантаження хімічними речовинами на легені у дорослого населення м. Кривий Ріг в 7,7 разів вища, ніж у м. Чернівці. Для дитячого населення м. Кривий Ріг доза навантаження в 4,58 разів вища, ніж у дорослого населення міста при аналогічному рівні забруднення (табл. 6).

3 метою більш досконалого наукового обгрунтування нами було проведено аналіз оцінки ризиків. На відміну від аналізу середньодобових і максимально разових ГДК, система оцінки ризиків враховує безпосередню дію речовин і чутливість різних груп населення, а також передбачає, що деякі речовини мають безпороговий канцерогенний або мутагенний вплив та враховує можливість одночасної шкідливої дії декількох речовин.

Таблиця 8

\begin{abstract}
Неканцерогенний ризик впливу шкідливих хімічних речовин атмосферного повітря на населення
\end{abstract} (за максимально разовою концентрацією)

\begin{tabular}{|c|c|c|c|c|}
\hline \multirow{2}{*}{$\begin{array}{c}\text { Хімічна речовина } \\
\text { (максимальноразова } \\
\text { концентрація) }\end{array}$} & \multirow{2}{*}{$\begin{array}{l}R f C, * \\
\text { мГ/M }\end{array}$} & \multicolumn{2}{|c|}{$\begin{array}{c}\text { Коефіціснт } \\
\text { небезпеки HQ }\end{array}$} & \multirow{2}{*}{$\begin{array}{c}\text { Критичні органи } \\
\text { та системи }\end{array}$} \\
\hline & & $\begin{array}{l}\text { м. Чер- } \\
\text { нівці } \\
\end{array}$ & $\begin{array}{c}\text { м. Кривий } \\
\text { Ріг } \\
\end{array}$ & \\
\hline Пил & 0,2 & 0,2 & 12,0 & Органи дихання \\
\hline Діоксид сірки & 0,5 & 0,11 & 0,13 & Органи дихання \\
\hline Оксид вуглецю & 1,0 & 0,8 & 12,0 & ЦНС, ССС, кров \\
\hline Діоксид азоту & 1,1 & 1,0 & 0,5 & Органи дихання \\
\hline Оксид азоту & 0,4 & 0,2 & 0,25 & Органи дихання \\
\hline Фенол & 1,7 & 1,3 & 0,01 & $\begin{array}{l}\text { ССС, нирки, } \\
\text { ЦНС, печінка }\end{array}$ \\
\hline Фтористий водень & 1,6 & 1,5 & - & $\begin{array}{l}\text { Органи дихання, } \\
\text { кісткова система }\end{array}$ \\
\hline Хлористий водень & 3,2 & 4,1 & - & Органи дихання \\
\hline Формальдегід & 0,035 & 1,2 & 3,37 & $\begin{array}{l}\text { Органи дихання, } \\
\text { імунна система }\end{array}$ \\
\hline Загальне НI & & 10,4 & 28,26 & \\
\hline НІ для органів дихання & & 8,31 & 16,25 & \\
\hline
\end{tabular}


Розрахунок коефіцієнту небезпеки було проведено з урахуванням тропності шкідливої хімічної речовини на окремі органи та системи. Як свідчать результати попередніх наукових досліджень, при впливі компонентів суміші на одні і ті ж органи або системи організму найбільш імовірним типом їх комбінованого впливу $\epsilon$ сумація (адитивність). Це правило не є універсальним, оскільки не враховує можливої різниці у механізмах специфічної дії компонентів суміші, а також локальних шкідливих реакцій у місці первинного контакту речовини з організмом (наприклад, слизових оболонках дихальних шляхів або шлунку). Разом з тим, на думку закордонних дослідників, такий підхід хоча і може перебільшувати небезпеку для здоров'я, однак має більшу перевагу у порівнянні з роздільною, незалежною оцінкою кожного із компонентів.

Дослідженнями встановлено, що для населення м. Чернівці індекс небезпеки від комбінованого впливу хімічних речовин за середньомісячною концентрацією на розвиток неканцерогенного ефекту складає лише 42,2\% від допустимого $\left(\mathrm{HI}_{0}=9\right)$, тоді як для населення м. Кривий Ріг даний показник сягає 135,5\%. Індекс небезпеки від комбінованого впливу хімічних речовин на розвиток неканцерогенного ефекту для органів дихання в м. Кривий Ріг в 3,3 разів перевищує аналогічний показник для населення м. Чернівці та на 60\% вищий за допустимий рівень (таблиця 7).

При аналізі індексу небезпеки від комбінованого впливу хімічних речовин за максимальноразовою концентрацією на розвиток неканцерогенного ефекту для мешканців м. Чернівців складає 115,5\% від допустимого $\left(\mathrm{HI}_{0}=9\right)$, для населення м. Кривий Ріг зазначений показник в 4,0 разів вищий за допустимий $\left(\mathrm{HI}_{0}=7\right)$. Індекс небезпеки від комбінованого впливу хімічних речовин на розвиток неканцерогенного ефекту для органів дихання від максимальних концентрацій для населення м. Кривий Ріг в 1,96 разів вищий, ніж для населення м. Чернівці і в 3,3 разів вищий за допустимий $\left(\mathrm{HI}_{0}=5\right)$ (таблиця 8).

Цей ризик розрахований за фактичними концентраціями шкідливих хімічних речовин в атмосферному повітрі м. Чернівці та Кривий Ріг, що підтверджується і доповнюється аналізом первинної захворюваності органів дихання досліджуваних регіонів. 


\section{ВИСНОВКИ}

Умови праці працівників основних професій сучасного гірничозбагачувального та металургійного виробництва й на сьогоднішній день продовжують залишатись шкідливими, важкими та напруженими за рахунок пилу переважно фіброгенної дії та шкідливих хімічних речовин, наявність яких на робочих місцях 60\% працівників сучасного гірничо-збагачувального підприємства відносить умови праці за цим показником до 3 класу 3 ступеня шкідливості, важкими умовами праці, які відносяться до 3 класу 2 ступеня шкідливості, несприятливим мікрокліматом 3 класу 2 ступеню шкідливості, еквівалентним рівнем шуму, що може досягати 3 класу 3 ступеню шкідливості. Особливістю умов праці сучасної гірничозбагачувальної галузі є технологічні операції, машини та механізми, які генерують вібрацію рівень якої може сягати 3 класу 2 ступеню шкідливості.

Викиди на одну особу по місту Кривий Ріг вищі в 13,6 разів

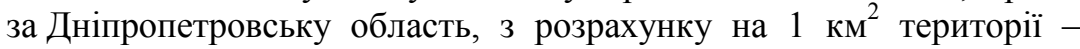
в 1,9 рази, а гранично допустимі максимально разові концентрації перевищують для пилу в 3,8-4,8 разів, оксиду вуглецю 2,4 разів, діоксиду азоту в 2,00-2,75 разів, фенолу в 1,40-1,80 разів, формальдегіду в $1,74-3,37$ разів.

При аналізі даних санітарно-гігієнічного моніторингу атмосферного повітря встановлено, що гранично допустимі максимально разові концентрації перевищують для пилу в 3,8-4,8 разів, оксиду вуглецю 2,4 разів, діоксиду азоту в $2,00-2,75$ разів, фенолу в 1,40 1,80 разів, формальдегіду в 1,74-3,37 разів, а індекс комплексного забруднення атмосфери становить по м. Кривий Ріг 13,51, а у контрольній групі - 3,657, що відповідно у 3,69 разів вище. Індекс небезпеки від комбінованого впливу хімічних речовин на розвиток неканцерогенного ефекту для населення м. Кривий Ріг у 4,0 рази вищий за допустимий $(\mathrm{HI} 0=7)$.

\section{АНОТАЦІЯ}

Дослідження присвячене поглибленому гігієнічному вивченню стану умов праці працівників промислових підприємств та якості атмосферного повітря екологічно небезпечного регіону. Доведено, що атмосферні забруднення серед багатьох чинників, які впливають на довкілля та здоров'я населення, є одним з головних, а у структурі економічних втрат валового внутрішнього продукту від смертності і 
захворюваності населення займають друге місце. Викиди на одну особу по місту Кривий Ріг вищі в 13,6 разів за Дніпропетровську область, з розрахунку на $1 \mathrm{kм}^{2}$ території - в 1,9 рази, а гранично допустимі максимально разові концентрації перевищують для пилу в 3,8-4,8 разів, оксиду вуглецю 2,4 разів, діоксиду азоту в 2,002,75 разів, фенолу в $1,40-1,80$ разів, формальдегіду в $1,74-3,37$ разів. Встановлено, що гранично допустимі максимально разові концентрації перевищують для пилу в 3,8-4,8 разів, оксиду вуглецю 2,4 разів, діоксиду азоту в $2,00-2,75$ разів, фенолу в $1,40-1,80$ разів, формальдегіду в 1,74-3,37 разів, а індекс комплексного забруднення атмосфери становить по м. Кривий Ріг 13,51, а у контрольній групі 3,657, що відповідно у 3,69 разів вище. Індекс небезпеки від комбінованого впливу хімічних речовин на розвиток неканцерогенного ефекту для населення м. Кривий Ріг у 4,0 рази вищий за допустимий $(\mathrm{HI} 0=7)$. Умови праці працівників основних професій сучасного гірничо-збагачувального та металургійного виробництва за рахунок пилу переважно фіброгенної дії та шкідливих хімічних речовин відносять до 3 класу 3 ступеня шкідливості, важкими умовами праці, які відносяться до 3 класу 2 ступеня шкідливості, несприятливим мікрокліматом 3 класу 2 ступеню шкідливості, еквівалентним рівнем шуму, що може досягати 3 класу 3 ступеню шкідливості. Особливістю умов праці сучасного гірничо-збагачувального виробництва $\epsilon$ технологічні операції, машини та механізми, які генерують вібрацію, рівень якої може сягати 3 класу 2 ступеню шкідливості.

\section{ЛІТЕРАТУРА}

1. Турос O.I., Маремуха Т.П., Петросян А.А., Брезицька Н.В. Дослідження забруднення атмосферного повітря зваженими частинками пилу (PМ та $\left.\mathrm{PM}_{10}\right)$ у м. Києві. Довкілля та здоров'я. 2018. № 4. C. 36-39. https://doi.org/ 10.32402/ dovkil2018.04.036.

2. Черниченко I.О., Баленко Н.В., Цимбалюк С.М., Осташ О.М. Про можливі механізми впливу атмосферних забруднень формальдегідом на формування захворюваності населення на рак щитоподібної залози. Довкілля та здоров'я. 2016. № 2. С. 9-13.

3. Добровольская Л.А., Клюев Д.С. Прогнозирование степени загрязнения атмосферного воздуха в промышленном регионе. Вісник приазовського державного технічного університету. 2018. Вип. 36. С. 216-223. doi: 10.31498/2225-6733.36.2018.142552. 
4. Гребняк М.П., Федорченко Р.А. Принципи профілактики шкідливого впливу індустріальних атмосферних забруднень на стан здоров'я населення. Довкілля та здоров'я. 2018. № 1. С. 51-56. https://doi.org/10.32402/dovkil2018.01.051.

5. Карелин А.О., Ломтев А.Ю., Мозжухина Н.А., Еремин Г.Б., Никонов В. А. Методические проблемы мониторинга мелкодисперсных частиц в атмосферном воздухе населенных мест. Гигиена и санитария. 2016. 95(10). С. 985-988. doi.org/10.1882/ 0016-9900-2016-10-985-988.

6. Давиденко Г.М. Гігієнічна оцінка небезпеки здоров'ю населення від забруднення атмосферного повітря зваженими частками пилу : автореф. дис. ... канд. біол. наук : 14.02.01. Київ, 2017. 24 с.

7. Гребняк М.П., Федорченко Р.А. Гігієнічна дозонологічна діагностика впливу атмосферних забруднень на органи дихання. Довкілля та здоров'я. 2017. № 1. С. 15-18.

8. База даних Держкомстату. URL: http://www.ukrstat.gov.ua (дата звернення: 01.10.2020).

\section{Information about the author:} Pavlenko O. I.,

Candidate of Medical Sciences, Senior Researcher, Head of the Laboratory of Industrial Aerosols Ukrainian Research Institute of Industrial Medicine 40, Vinohradova str., Kryvyi Rih, Dnipropetrovsk Region, 50096, Ukraine

Oriekhova O. V.,

Candidate of Medical Sciences, Senior Researcher, Head of the Laboratory of Industrial Microclimate and Physiology of Heat Exchange Ukrainian Research Institute of Industrial Medicine 40, Vinohradova str., Kryvyi Rih, Dnipropetrovsk Region, 50096, Ukraine 